\title{
Multiple comparisons of diversity indices invaded by Lantana camara
}

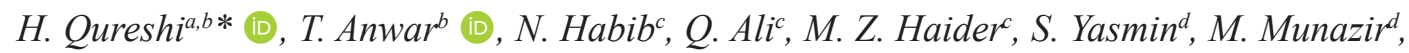 \\ Z. Basite and M. Waseem ${ }^{f}$ \\ ${ }^{a}$ Institute of Biological Sciences, Gomal University, Dera Ismail Khan-29050, Pakistan \\ bepartment of Botany, Pir Mehr Ali Shah Arid Agriculture University, Rawalpindi-46300, Pakistan \\ 'Department of Botany, Government College University, Faisalabad-38000, Pakistan \\ ${ }^{\mathrm{d}}$ Department of Botany, Government College for Women University, Sialkot-51310, Pakistan \\ ${ }^{e}$ Department of Mathematics \& Statistics, Pir Mehr Ali Shah Arid Agriculture University, Rawalpindi-46300, Pakistan \\ fDepartment of Biology, Allama Iqbal Open University, Islamabad-44000, Pakistan \\ *e-mail: drhuma@gu.edu.pk; humaqureshi8@gmail.com
}

Received: April 02, 2019 - Accepted: September 25, 2019 - Distributed: February 28, 2021

(With 5 figures)

\begin{abstract}
Current study assessed the impact of Lantana camara invasion on native plant diversity in Pothohar region of Pakistan. The approach used for study was random samplings and comparisons of diversity indices [number of species (S), abundance $(N)$, species richness $(R)$, evenness $\left(J^{\prime}\right)$, Shannon diversity index $\left(H^{\prime}\right)$ and Simpson index of dominance $(\lambda)$ ] with two categorical factors i.e., invaded and non-invaded (control). Control plots harboured by an average of 1.74 more species $/ 10 \mathrm{~m}^{2}$. The control category was diverse $\left(\mathrm{H}^{\prime}=2.56\right)$ than invaded category $\left(\mathrm{H}^{\prime}=1.56\right)$. The higher value of species richness in control plots shows heterogeneous nature of communities and vice versa in invaded plots. At multivariate scale, ordination (nMDS) and ANOSIM showed significant magnitude of differences between invaded and control plots at all sites. The decrease in studied diversity indices in invaded over control sites indicated that plant communities become less productive due to Lantana invasion.
\end{abstract}

Keywords: phytosociological study, plot comparisons, multivariate analysis, non-metric multidimensional scaling, invasion impacts, diversity conservation.

\section{Análises múltiplas de índices de diversidade da invasiva Lantana camara}

\section{Resumo}

O presente estudo avaliou o impacto da invasão de Lantana camara na diversidade de plantas nativas na região de Pothohar, no Paquistão. A abordagem utilizada para o estudo foram a amostragem aleatória e a comparação de índices de diversidade, como número de espécies $(\mathrm{S})$, abundância $(\mathrm{N})$, riqueza de espécies $(\mathrm{R})$, equitabilidade $\left(\mathrm{J}^{\prime}\right)$, índice de diversidade de Shannon ( $\left.\mathrm{H}^{\prime}\right)$ e índice de dominância de Simpson $(\lambda)$, com dois fatores categóricos, ou seja, invadidos e não invadidos (controle). As parcelas não invadidas tinham, em média, 1,74 espécie a mais $/ 10 \mathrm{~m}^{2}$ que parcelas invadidas. A categoria controle foi mais diversa $\left(\mathrm{H}^{\prime}=2,56\right)$ do que a categoria invadida $\left(\mathrm{H}^{\prime}=1,56\right)$. O maior valor da riqueza de espécies em parcelas de controle mostra a natureza heterogênea das comunidades, e vice-versa, em parcelas invadidas. Na escala multivariada, ordenação (nMDS) e ANOSIM mostraram magnitude significativa das diferenças entre as parcelas invadidas e controle em todos os locais. A diminuição nos índices de diversidade estudados em locais invadidos por controle indicou que as comunidades de plantas se tornam menos produtivas por causa da invasão de Lantana.

Palavras-chave: estudo fitossociológico, comparações de parcelas, análise multivariada, escala multidimensional não métrica, impactos da invasão, conservação da diversidade.

\section{Introduction}

Global Invasive Species Program (GISP, 2020) defines an invasive species as "[...] non-native organisms that cause/have the potential to cause harm to the environment, economies, or human health". Unwanted effects of such species may include reduced soil value, an increase in the rate of soil erosion, water bodies choking thus affecting the quality of water, alteration in the composition of natural fauna and flora, risk to human health and economic losses (Marwat et al., 2010), soil nutrient composition, hydrology modification, forest fire cycle and other ecosystem processes 
(Dogra et al., 2010), reduction in water availabilities, agricultural yields and grazing areas, contributing to spread of vector borne diseases (Etana, 2013). Due to their potential to outcompete and replace native species, invasive species are the second leading cause of biodiversity loss after habitat destruction. Keeping in view impact of invasive weeds on the environment, article 8 (h) of the Convention on Biological Diversity (CBD) signed by 161 countries at the Earth Summit in 1992; urges the parties to "[...] prevent the introduction of, control, or eradicate those alien species which threaten ecosystems, habitat or species [...]" (Qureshi et al., 2014, p. 408). The impact of exotic invasive plants on native organisms is widely acknowledged but poorly understood. Studying the community level impacts of invader identify its potential effects and provide valuable information for management and nature conservation strategies (Hejda et al., 2009).

Sage plant is medium-sized, perennial, aromatic, ornamental shrub, native to the Neotropics. It is now established in over 60 countries, rated among top ten worst weeds around the world (Qureshi et al., 2014). The shrub was introduced throughout the tropics and subtropics during the late 19th century, often used as a hedge plant (Shaukat et al., 2003) (Figure 1). Adverse effects of Lantana on ecosystems include damaged ecosystem services, soil erosion, reduced native biodiversity, encroaching on agricultural land, animal poisoning, harboring disease vectors and allelopathic effects resulting in reduced or no growth of associated flora. Phenotypic plasticity, high reproductive potential, immunization to grazing pressure, allelopathy and fire tolerance contributes to its invasiveness (Bhakat and Maiti, 2012). Lantana is strongly allelopathic and interferes with the growth and development of a wide range of plants, including ferns, vines, crops and other plants even its own populations (Ambika et al., 2003). The major allelopathic compounds found in Lantana weed are salicylic acid, gentisic acid, coumarin, p-hydroxybenzoic acid, ferulic acid, lantadene A, 6-methyl coumarin, lantadene B, oleanolic acid, lantalonic acid, icterogenin, lantolonic, ursolic acid and oleonolic acid (Yadav et al., 2016).

Lantana is one of the worst weeds presently known in Pakistan. No previous study has reported from Pothohar region regarding its ecological impacts. The current study was carried out to find out (1) what is the effect of Lantana weed on diversity indices in different districts of the Pothohar region (assuming each district as 'site'); (2) do the effects on diversity differ between different sites (districts) in the area?

\section{Material and Methods}

\subsection{Study area}

The Pothohar is a north-eastern plateau in Pakistan, making the northern part of Punjab. It edges Azad Kashmir (the western parts) and Khyber Pakhtunkhwa (southern parts). Pothohar Zone extends from $32.5^{\circ} \mathrm{N}$ to $34.0^{\circ} \mathrm{N}$ Latitude and $72^{\circ} \mathrm{E}$ to $74^{\circ} \mathrm{E}$ Longitude and lies between Indus and Jhelum River. The plateau expanses from salt range northward to the foothills of Himalayas. The Pothohar region embraces Jhelum $\left(32.9405^{\circ} \mathrm{N}, 73.7276^{\circ} \mathrm{E}\right)$, Islamabad $\left(33.73^{\circ} \mathrm{N}\right.$, $\left.73.09^{\circ} \mathrm{E}\right)$, Attock $\left(33.76^{\circ} \mathrm{N}, 72.36^{\circ} \mathrm{E}\right)$, Rawalpindi $\left(73.04^{\circ} \mathrm{E}\right.$, $\left.33.59^{\circ} \mathrm{N}\right)$, and Chakwal $\left(72.85^{\circ} \mathrm{E}, 32.93^{\circ} \mathrm{N}\right)$ districts. Total area of Pothohar region is $28488.9 \mathrm{Sq}$. Km. (Rashid and Rasul, 2011). Pothohar region has an extreme climate with hot summers and cold winters. Weather is divided into four seasons; Cold (December-March); Hot (April-June); Monsoon (July-September) and Post-Monsoon season (October-November). This area practices an average annual rainfall of $812 \mathrm{~mm}$, about half of which occurs in the Monsoon months (July-September). The mean maximum temperature rises till the month of June and then falls appreciably with the advent of rains being the coldest in January $\left(14.62-18.7^{\circ} \mathrm{C}\right)$. Average temperatures

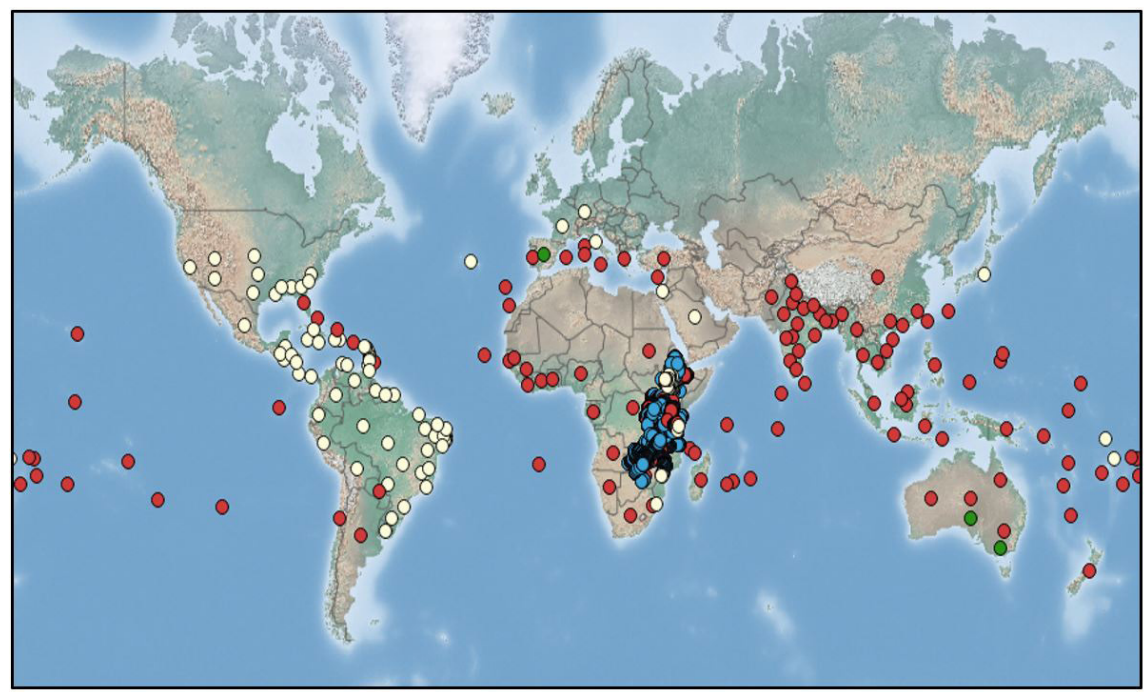

- Invasive

- Naturalized

- Not-invasive

○ Not-recorded

Figure 1. Distribution map and invasion status of invasive L. camara around the globe. 
range from $14^{\circ} \mathrm{C}$ in January to $37^{\circ} \mathrm{C}$ in June (Pakistan Meteorological Department, University Road Karachi, Pakistan). The region has broadly four types of soil; loess, river alluvium, residual and piedmont alluvium. Due to dynamic climate and combination of hills and plains, Pothohar region is rich in biodiversity (Shabbir et al., 2012; Ghufran et al., 2013).

\subsection{Experimental eesign}

Field work was carried out during July-August (being the maximum growth period of plants), 2016. The effect of invasion was studied in each of five districts (Attock, Chakwal, Jhelum, Islamabad \& Rawalpindi). Ecological indices for selected invaders were calculated and compared at various sites. The sampling technique was random. For each district six invaded and six non-invaded paired vegetation plots (each $3.16 \times 3.16 \mathrm{~m}$ in size, i.e., $10 \mathrm{~m}^{2}$ in the area) were sampled. The plots were chosen to cover a range of site conditions and vegetation types in which the invader achieves dominance in the invaded communities. Plot of invaded vegetation ('invaded plot') where the invader showed dominance was considered as 'treatment' and a second vegetation plot, usually $0.5-1 \mathrm{~km}$ apart from treatment, where invader has no dominance ('non-invaded plot') was considered as the "control". The estimated density of the weed in the area across locations was $4 / \mathrm{m}^{2}$. In all, 60 vegetation plots were sampled (consisting of 6 paired samples per district, and hence 30 treatments; 30 controls for the entire Pothohar region) (Figure 2). Within each randomly chosen plot $\left(10 \mathrm{~m}^{2}\right.$ in area), all vascular plant species in control and invaded plots were identified to species level.

\subsection{Data analyses}

Species frequency data were created and invasion impacts of $L$. camara on local flora were assessed by calculating and comparing ecological indices including Margalef's index of richness, Shannon-Weaver index of diversity, Simpson index of dominance and index of evenness for control and invaded sites. These parameters were calculated according to equations 1-4:

Margalef's index of richness $(\mathrm{R})=\frac{\mathrm{S}-1}{\ln \mathrm{N}}$

Where, $\mathrm{N}=$ Total number of individuals

$\mathrm{S}=$ Total number of species.

Shannon - Weaver index of diversity $\left(H^{\prime}\right)=-\sum_{i=1}^{S}\left(\frac{n_{i}}{N} \times \ln \frac{n_{i}}{N}\right)$

Where, $\mathrm{N}=$ Total number of individuals of all species $\mathrm{n}=$ Actual number of individuals of one species.

Simpson index of dominance $(\lambda)=1-\frac{\sum_{\mathrm{i}=1}^{\mathrm{S}} \mathrm{n}_{\mathrm{i}}\left(\mathrm{n}_{\mathrm{i}}-1\right)}{\mathrm{N}(\mathrm{N}-1)}$

$\mathrm{N}=$ Total number of individuals of all species

$\mathrm{n}=$ Number of individuals of one species

Index of evenness $(E)=\frac{H^{\prime}}{\ln S}$

Where H' is Shannon's index

$\mathrm{S}=$ Number of species.

Rarefaction curves were plotted to determine if sampling was adequate in each district using observed, Coleman's, Jackknife, Bootstrap and Chao2 models in

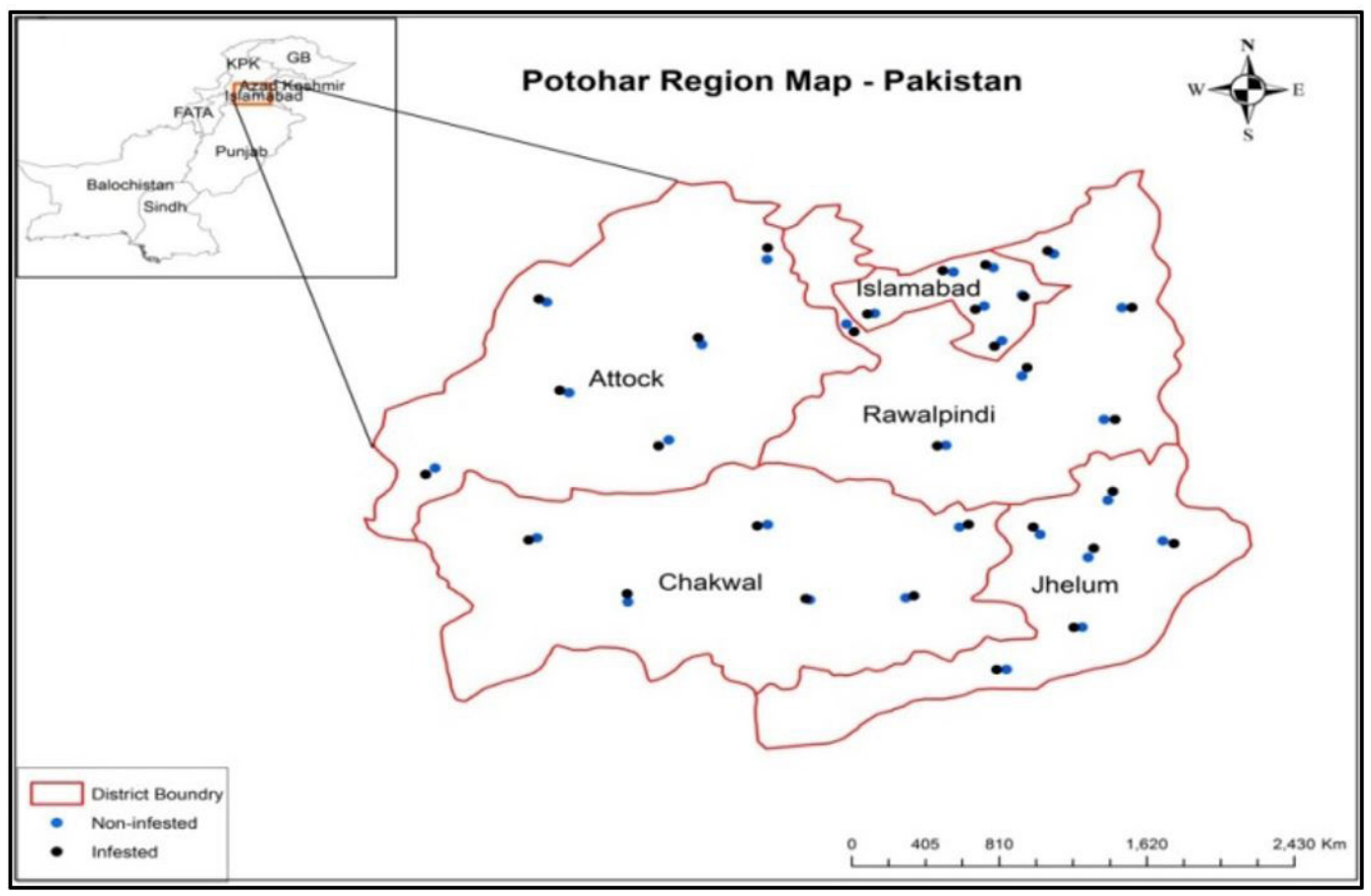

Figure 2. Distribution of plots for impact analysis of $L$. camara in Pothohar region. 
PRIMER v. 7 (Clarke and Warwick, 2001). All gave comparable results; consequently only that of real (observed) data are presented. Data were then subjected to univariate and multivariate analyses of non-metric multidimensional scaling procedure (Clarke and Gorley, 2015). Data were log transformed to achieve criteria of normality (evenness and Simpson index of diversity). For invasion impact analysis, diversity indices including total number of species $(\mathrm{S})$, abundance $(\mathrm{N})$, species richness $(\mathrm{R})$, species evenness $\left(J^{\prime}\right)$, Shannon index of diversity $\left(\mathrm{H}^{\prime}\right)$ and Simpson index of dominance $(\lambda)$ were calculated for control as well as for invaded plots. The above ecological indices were subjected to analysis of variance (ANOVA) with invasion status and districts as factors using IBM SPSS v. 21. Differences between ecological indices for five districts were individually tested for significance between invaded and control plots by multiple comparisons tests of t-test. Data were further analysed for species assemblages by non-metric multidimensional scaling (nMDS) in two-three dimensions with invasion status (control, invaded) as factor using PRIMER V.7 software. nMDS was used to ordinate the similarity of data between site categories (invaded, control) based on Bray-Curtis dissimilarity matrix following log-transformation of species abundance data due to zero species count in some plots. The range of clustering of sites and locations in response to invasion were assessed by analysis of similarity (ANOSIM) and similarity percentage (SIMPER). ANOSIM relates mean difference of ranks between and within groups, generating the Global statistic (R). The values of Global statistic (R)

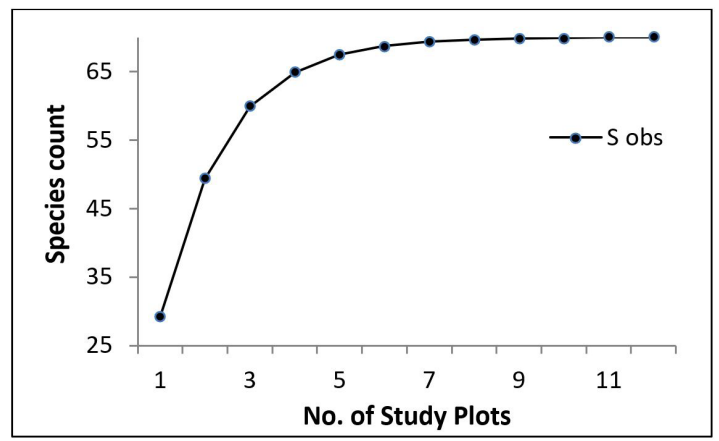

Figure 3. Rarefaction curve showing cumulative number of species recorded as a function of sampling effort. range from -1 to +1 . Values near 0 and negative values demonstrate similarity among groups. Values impending +1 indicate a strong dissimilarity among groups (Clarke and Warwick, 2001; Qureshi et al., 2019). SIMPER identified species contributed most to average dissimilarity between groups (invaded and control plots). This technique calculates average impact of each species contributing to dissimilarity between groups (Clarke and Warwick, 2001). Values of percentage similarity between groups range between 0 to 100 , with 100 stating maximum similarity.

\section{Results}

To assess sampling completeness, rarefaction curves plotting cumulative number of species as a function of sampling effort were used which indicated that sampling was reasonably complete (Figure 3). A total of 66 plant species from 59 genera were documented during the study (Supplementary file). A total of 56 species were recorded in control plots compared with 37 in infested plots. Mean species diversity and richness/quadrat was higher in control plots (Figure 4).

Comparisons of ecological indices showed significant differences across sites and invasion status (Table 1). Lantana invasion exhibited variable impact in five sites by reducing species number per plot (S) and abundance (N) by a maximum of $46 \%$ in Chakwal. Control plots harbored on average $13.90 \pm 3.50($ mean $\pm S D, n=30)$ species. This was by $1.734 \pm 0.14$ more than invaded plots and the difference was significant $(\mathrm{t}=2.27, \mathrm{df}=29, \mathrm{p}=0.00)$. In total, 212 and 139 individuals were recorded in control and invaded plots respectively. Similarly, abundance in control and invaded plots differed by $2.3 \pm 1.80$ (mean $\pm \mathrm{SD}$, $\mathrm{n}=30)$ and the difference was significant $(\mathrm{t}=4.08, \mathrm{df}=29$, $\mathrm{p}=0.00$ ). Control plots also exhibited higher values of species richness by a difference of $0.15 \pm 0.41$, species evenness by $0.019 \pm 0.12$; Shannon index of diversity by $0.20 \pm 0.40$ and Simpson index of dominance by $0.22 \pm 1.27$ (Table 2).

For individual district, native flora differed significantly in species density $(\mathrm{S})$, abundance per plot $(\mathrm{N})$, species evenness $\left(J^{\prime}\right)$ and Simpson index of dominance $(\lambda)$ but not in overall species richness $(\mathrm{R})$ and Shannon index of diversity $\left(\mathrm{H}^{\prime}\right)$. Lantana invasion had significant impacts on all ecological indices except species evenness $\left(\mathrm{J}^{\prime}\right)$ at

Table 1. Summary ANOVA of invasion impacts and site on diversity indices of local plant community.

\begin{tabular}{|c|c|c|c|c|c|}
\hline \multirow[b]{2}{*}{ Ecological index } & \multicolumn{3}{|c|}{ SUMMARY ANOVA } & \multicolumn{2}{|c|}{ Mean ( $($ SD) } \\
\hline & $\begin{array}{l}\text { Site } \\
(\mathrm{S})\end{array}$ & $\begin{array}{c}\text { Invasion } \\
\text { status (IS) }\end{array}$ & $\begin{array}{c}\mathrm{S}^{\mathrm{x} I S} \\
\text { Interaction }\end{array}$ & $\begin{array}{c}\text { Control } \\
\text { (30) }\end{array}$ & $\begin{array}{c}\text { Invaded } \\
(30)\end{array}$ \\
\hline No. of species $(\mathrm{S}) / 10 \mathrm{~m}^{2}$ & $* * *$ & $* * *$ & $* * *$ & $13.90 \pm 3.50$ & $12.166 \pm 2.78$ \\
\hline Abundance $(\mathrm{N}) / 10 \mathrm{~m}^{2}$ & $* * *$ & $* * *$ & $* * *$ & $17.6667 \pm 1.75$ & $16.66 \pm 2.50$ \\
\hline Species Richness (R) & $* * *$ & $* * *$ & $* * *$ & $3.74 \pm 0.72$ & $2.7 \pm 0.91$ \\
\hline Species evenness $\left(\mathrm{J}^{\prime}\right)$ & $* * *$ & $* * *$ & $* *$ & $0.98 \pm 0.005$ & $0.92 \pm 0.25$ \\
\hline Shannon index of diversity $\left(\mathrm{H}^{\prime}\right)$ & $* * *$ & $* * *$ & $* * *$ & $2.56 \pm 0.27$ & $1.56 \pm 0.65$ \\
\hline Simpson index of dominance $(\lambda)$ & $* * *$ & $* * *$ & $* * *$ & $0.27 \pm 0.23$ & $0.17 \pm 0.08$ \\
\hline
\end{tabular}

\pm SD indicates 'standard deviation'; $* * * \mathrm{P} \leq 0.001 ; * * \mathrm{P} \leq 0.02$ 
site 1 (Attock). For site 2 (Chakwal), only species richness was affected significantly. For site 3 (Islamabad) invasion impacts were not significant on native species evenness while all ecological indices were significantly affected for site 4 (Jhelum) and site 5 (Rawalpindi) (Table 2).
The ordination (nMDS) and ANOSIM showed significant magnitude of differences between species composition of invaded and control plots in all sites with global $\mathrm{R}$ values of $1.00(p=0.002), 0.974(p=0.002), 0.728(p=0.002)$, $0.983(\mathrm{p}=0.002)$ and $0.930(\mathrm{p}=0.002)$ for Attock, Chakwal,
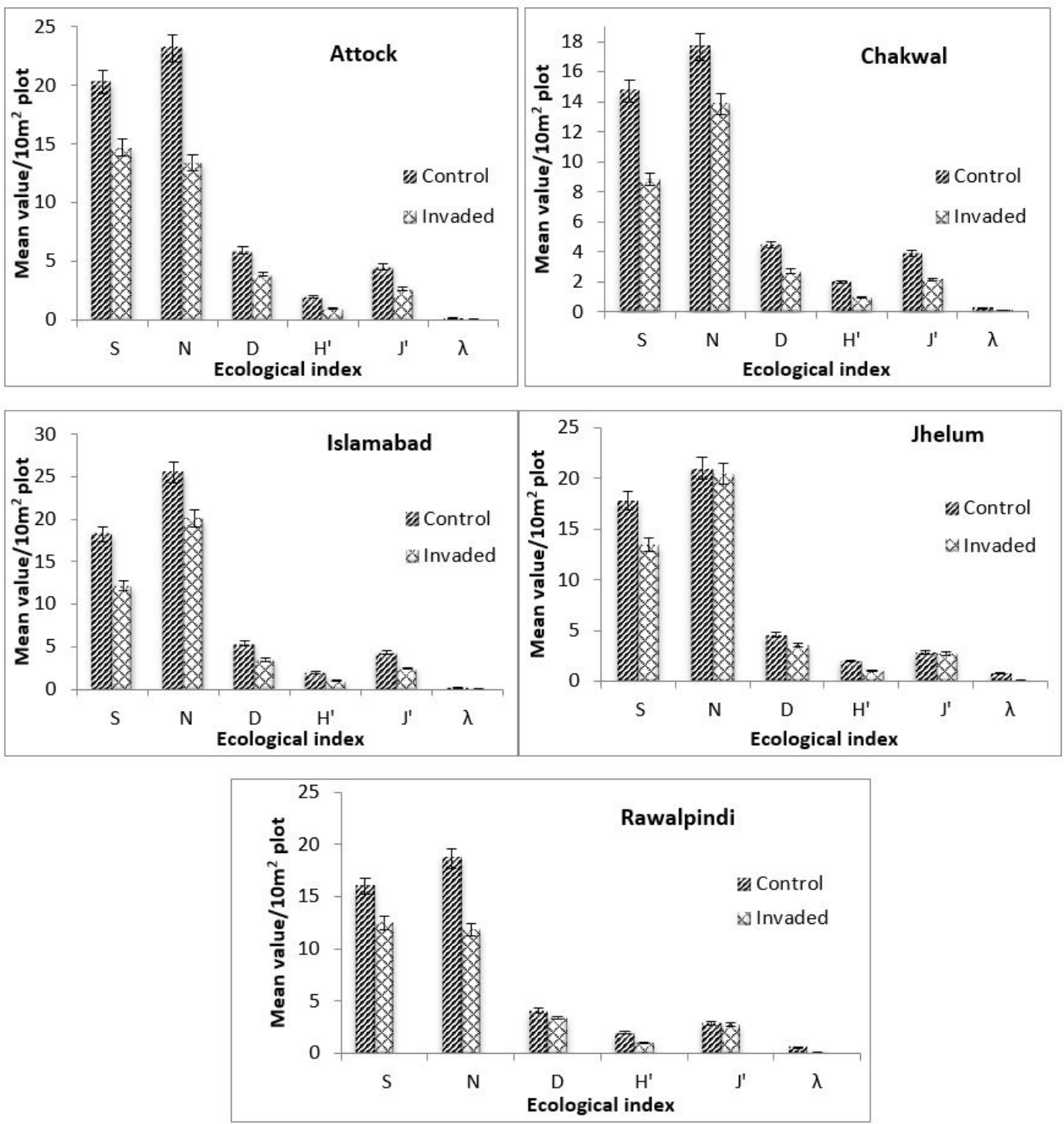

Figure 4. Mean values $/ 10 \mathrm{~m}^{2}$ for ecological indices of invaded vs control plots in different sites. $(\mathrm{S}=$ Number of species; $\mathrm{N}=$ Abundance; $\mathrm{D}=$ Species richness; $\mathrm{H}^{\prime}=$ Shannon index of diversity; $\mathrm{J}^{\prime}=$ Species evenness; $\lambda=$ Simpson index of dominance).

Table 2. Student's t-test for significance of differences between control and invaded plots.

\begin{tabular}{lcccccc}
\hline \multicolumn{1}{c}{ Site } & $\begin{array}{c}\text { Number of } \\
\text { species (S) }\end{array}$ & $\begin{array}{c}\text { Abundance } \\
(\mathbf{N})\end{array}$ & $\begin{array}{c}\text { Margalef's } \\
\text { index of } \\
\text { Richness (R) }\end{array}$ & $\begin{array}{c}\text { Species } \\
\text { Evenness ( } \mathbf{J} \text { ') }\end{array}$ & $\begin{array}{c}\text { Shannon } \\
\text { index of } \\
\text { Diversity (H') }\end{array}$ & $\begin{array}{c}\text { Simpson } \\
\text { index of } \\
\text { dominance }(\boldsymbol{\lambda})\end{array}$ \\
\hline Attock & $* * *$ & $* * *$ & $* * *$ & $\mathrm{NS}$ & $* *$ & $* * *$ \\
Chakwal & $\mathrm{NS}$ & $\mathrm{NS}$ & $* *$ & $\mathrm{NS}$ & $\mathrm{NS}$ & $\mathrm{NS}$ \\
Islamabad & $* *$ & $* *$ & $* *$ & $\mathrm{NS}$ & $* *$ & $* *$ \\
Jhelum & $* * *$ & $* * *$ & $* * *$ & $* * *$ & $* * *$ & $* * *$ \\
Rawalpindi & $* * *$ & $* * *$ & $* * *$ & $* *$ & $* * *$ & $* * *$ \\
\hline$* * * \mathrm{P} \leq 0.001 ; * * \mathrm{P} \leq 0.02$ & & & & & &
\end{tabular}




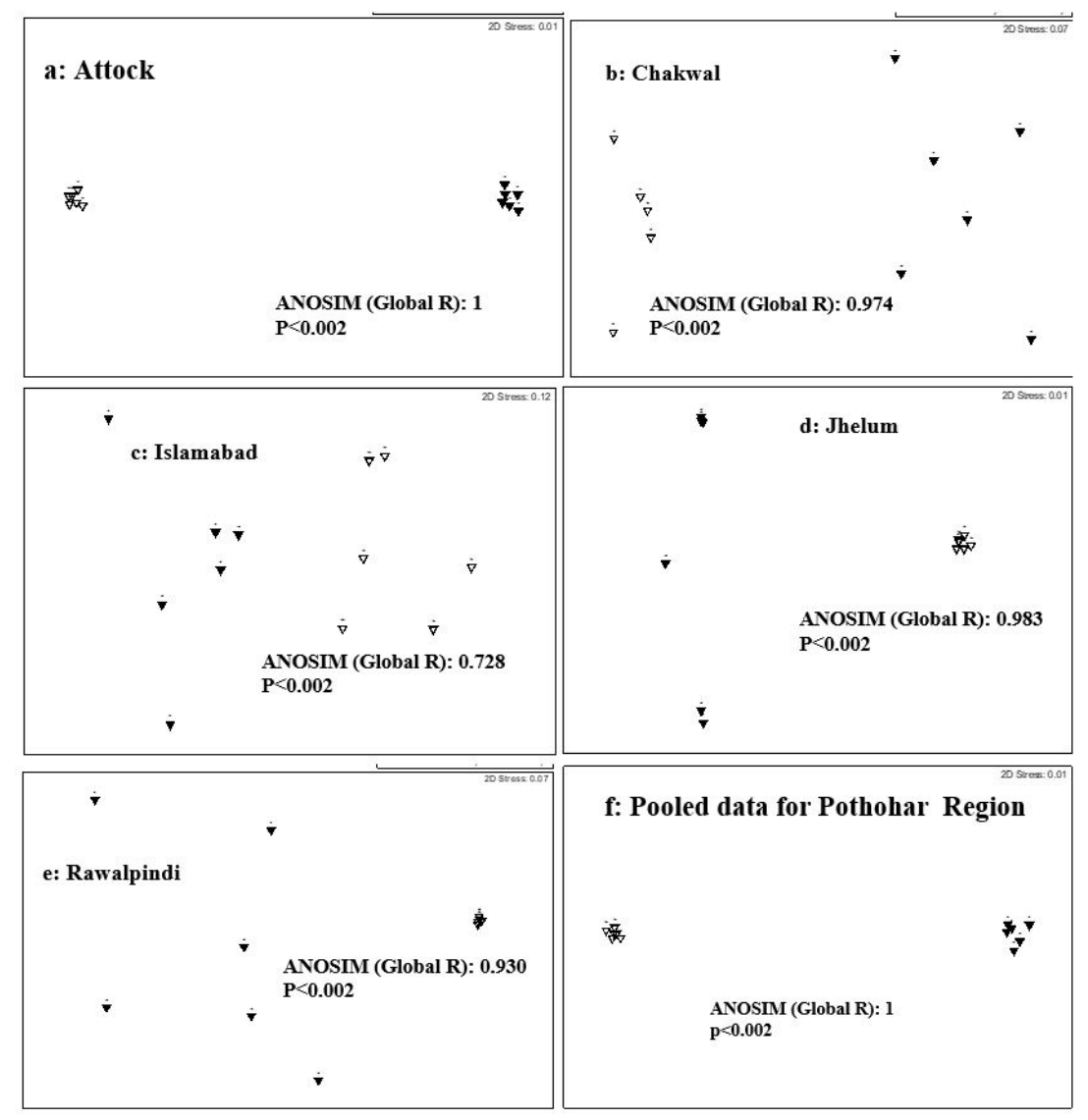

Figure 5. Multidimensional scaling (MDS) ordination and analyses of similarity (ANOSIM) results of invasion status data for Pothohar region, Pakistan; closed symbols are representative of invaded sites while open for control ones.

Table 3. SIPMER analysis of Lantana invaded and control sites in Pothohar region, Pakistan.

\begin{tabular}{lccccc}
\hline \multicolumn{1}{c}{ Species } & Average dissimilarity $=\mathbf{6 5 . 5 6 \%}$ & & \\
\hline \multicolumn{1}{c}{ Control } & Invaded & Av. Diss. & Diss/SD & Contribution (\%) \\
\hline Stellaria media (L.) Vill. & 3.04 & 1.71 & 1.38 & 7.99 & 2.10 \\
Oxalis corniculata L. & 2.98 & 0.00 & 1.35 & 9.94 & 2.06 \\
Cynodon dactylon (L.) Pers. & 2.81 & 1.82 & 1.27 & 9.48 & 1.94 \\
Digitaria ciliaris (Retz.) Koeler & 2.74 & 0.00 & 1.24 & 6.40 & 1.89 \\
Malva parviflora L. & 2.70 & 0.00 & 1.22 & 7.69 & 1.86 \\
Croton tiglium L. & 2.65 & 1.77 & 1.20 & 9.38 & 1.83 \\
Eclipta prostrata (L.) L. & 2.65 & 0.18 & 1.19 & 12.44 & 1.82 \\
Clematis grata (Wall.) Kuntze & 2.54 & 1.62 & 1.15 & 6.88 & 1.76 \\
Chenopodium album L. & 2.46 & 2.35 & 1.12 & 4.51 & 1.71 \\
Calotropis procera (Aiton) W.T.Aiton & 2.43 & 0.01 & 1.11 & 5.98 & 1.69 \\
Medicago sativa L. & 2.41 & 1.23 & 1.09 & 7.67 & 1.67 \\
Achyranthus aspra L. & 2.40 & 2.14 & 1.08 & 5.91 & 1.65 \\
Solanum nigrum L. & 2.38 & 2.31 & 1.06 & 9.35 & 1.64 \\
Datura stramonium L. & 2.37 & 2.18 & 1.07 & 9.14 & 1.63 \\
Sonchus asper (L.) Hill. & 2.25 & 1.49 & 1.02 & 8.80 & 1.55 \\
Digera muricata (L.) Mart & 2.15 & 2.21 & 0.98 & 6.44 & 1.49 \\
Bergenia ciliate (Haw.) Sternb. & 2.15 & 2.01 & 0.97 & 6.11 & 1.48 \\
Anagallis arvensis L. & 2.16 & 1.49 & 0.97 & 2.17 & 1.48 \\
Cannabis sativa L. & 2.12 & 2.38 & 0.96 & 6.36 & 1.46 \\
Portulaca oleracea L. & 2.11 & 2.41 & 0.96 & 3.12 & 1.46
\end{tabular}

Values are average abundance ranking (1-rare; 2-common; 3-very common; >4-dominant); Av. Diss. = Average dissimilarity; Diss/SD = Dissimilarity standard deviation. 
Islamabad, Jhelum and Rawalpindi, respectively (Figure 5). The greatest dissimilarity between invaded and control plots was noticed by Attock.

Similarity percentage (SIMPER) analysis of data suggested species contributing most to average dissimilarity between control and invaded groups. This analysis also computed average contribution of species causing dissimilarity. Few top species separating invaded plots from non-invaded plots (control) for analysis are enlisted in Table 3. Stellaria media, Oxalis corniculata, Cynodon dactylon, Digitaria ciliaris, Malva parviflora, Croton tiglium, Eclipta prostrata, Clematis grata, Chenopodium album, Calotropis procera, Medicago sativa, Achyranthus aspra, Solanum nigrum, Datura stramonium and Sonchus asper were top contributing species causing difference between control and invaded plots.

\section{Discussion}

Lantana weed is predominant in some countries in the world including Pakistan, Australia, India, and Africa (Goncalves et al., 2014). Lantana weed exerts impact on natural communities by displacing native species hence exert imbalance in natural ecosystems. Ecologically diversified adaptability of L. camara allows its rapid expansion resulting in reduction of native biodiversity and its monoculture formation. The chances of invasiveness of Lantana are high in future due to its rapid spread, high adaptability to different environments, tenacious resistance to cutting and burning and climate change (Taylor et al., 2012; Zhang et al., 2014). Measuring the impact of invasive species on native diversity by comparing invaded and non-invaded plots/sites collate large data sets, which give idea of variation in response of invaded community over a wider range of environments. However, this approach brings about some uncertainty over the character of invading plots prior to the invasion, i.e. to what extent are they comparable with uninvaded control plots as the plots may differ in factors other than the invasion (Hejda et al., 2009). In current study, the non-invaded plots were selected to be in close vicinity of the invaded stands with habitat conditions matching as closely as possible.

In present study, comparisons of ecological indices across invaded and control plots in Pothohar region (taken as biodiversity hotspot) of Pakistan indicated less diversity in invaded plots. These findings are in-line with other studies on alien invasive weeds, which indicated strong effects of the invader on ecosystem properties (Riaz and Javaid, 2011; Riaz and Javaid, 2010; Shabbir and Bajwa, 2007). In Pakistan, Lantana invasion is reported earlier from Rawalpindi and Islamabad (Malik and Husain, 2006; Fatimah and Ahmad, 2012; Khan et al. 2010). In current study, comparisons of ecological indices across invaded and control plots in Pothohar region indicated significant differences in ecological diversity indices. These findings are consistent with other studies on this invasive species, which indicated its strong effects on ecosystem properties (Lemma et al., 2015; Tadesse et al., 2017). Phenotypic plasticity, high reproductive potential, immunization to grazing pressure, allelopathy and fire tolerance contributes to invasiveness of Lantana (Bhakat and Maiti, 2012).

The results demonstrate differences in vegetation composition of invaded and control plots. Analysis of variance among invaded and control plots showed significant decrease in ecological indices across site and invasion status. These findings are consistent with other studies on invasive species indicating strong negative effects of invasive species on floral diversity and ecosystem properties (Manchester and Bullock, 2000; McNeely, 2001; Grice, 2006; Borokini, 2011; Jeschke et al., 2014; Panetta and Gooden, 2017).

Lantana invasion exhibited variable impacts in five sites (districts) by reducing species number per plot (S), abundance $(\mathrm{N})$, species richness $(\mathrm{R})$, species evenness $\left(\mathrm{J}^{\prime}\right)$, Simpson index of dominance $(\lambda)$ and Shannon index of diversity $\left(\mathrm{H}^{\prime}\right)$. The trend of decrease in ecological indices in invaded plots is similar to invasion studies on L. camara from Australia (Duggin and Gentle, 1998), Fiji (Taylor and Kumar, 2014), Eastern Africa (Shackleton et al. 2017), South Africa (Vardien et al., 2012), China (Fan et al., 2010), Ethiopia (Chanie and Assefa, 2015) and India (Dobhal et al., 2011; Priyanka and Joshi, 2013). In current study, we noticed negative effects of $L$. camara on all of ecological indices in invaded over control plots. The highest impact is noticed in Attock district.

The ordination (nMDS) and ANOSIM showed significant magnitude of differences between diversity indices of invaded and control plots. The difference was significant for all of five study sites but greatest dissimilarity between invaded and control plots were noticed by Attock. Invasion of L. camara was reported earlier as top invasive species from Attock region along two other species, viz. Prosopis juliflora and Xanthium strumarium (Malik and Husain, 2006). SIMPER analysis showed $65.56 \%$ overall dissimilarity among invaded and control plots. Analysis showed herbs to be most affected by Lantana invasion than shrubs and trees. These were Solanum nigrum, Parthenium hysterophorus, Ajuga bracteosa, Rumex dentatus, Typha domengensis, Malva parviflora, Tribulus terrestris and Oxalis corniculata. There are related studies reporting diversity loss due to Lantana invasion (Sharma et al., 2009; Gooden et al., 2009; Singh et al., 2014).

\section{Conclusions}

The increased occurrence of invasion around the world poses a major threat to native diversity. Plant invasions in novel areas deplete species diversity, alters native community composition, affect ecosystem process and thus cause huge ecological and economic imbalance. Invasive species studies in the past revealed that the effects of invasion are complex and can permanently alter the function and structure of communities, cause local annihilations and changes in ecosystem processes. Invasion by alien plant species affect the composition and dynamics of species on a wide scale and have great impact on ecosystem 
functions. The decrease in ecological diversity indices in invaded over control sites in present study indicated that plant communities become less productive due to Lantana invasion hence a threat to plant diversity of invaded areas. There is urgent need of appropriate control measures including use of proven biological control agents for this weed in Pakistan.

\section{Acknowledgements}

Pakistan Meteorological Department, University Road Karachi, Pakistan is acknowledged for providing climate data (2018) of Pothohar region, Pakistan.

\section{References}

AMBIKA, S.R., POORNIMA, S., PALANIRAJ, R., SATI, S.C. and NARWAL, S.S., 2003. Allelopathic plants. Lantana camara L. Allelopathy Journal, vol. 12, pp. 147-162.

BHAKAT, R.K. and MAITI, P.P., 2012. Invasiveness and allelopathy as a threat to biodiversity. In: Proceedings of the International Seminar on Multidisciplinary Approaches in Angiosperm Systematics, 2012, Kalyani. Kalyani: University of Kalyani, pp. 748-751.

BOROKINI, T.I., 2011. Invasive alien plant species in Nigeria and their effects on biodiversity conservation. Tropical Conservation Science, vol. 4, no. 1, pp. 103-110. http://dx.doi. org/10.1177/194008291100400110.

CHANIE, S. and ASSEFA, A., 2015. Impact of Invasion: a case study on the ecological and socioeconomic impact of Lantana camara (L.) in Abay Millennium Park (AMP). Journal of Ecology and the Natural Environment, vol. 3, pp. 288-309.

CLARKE, K.R. and GORLEY, R.N., 2015. PRIMER V7: user manual/tutorial. Plymouth: Plymouth Marine Laboratory.

CLARKE, K.R. and WARWICK, R.M., 2001. Change in marine communities: an approach to statistical analyses and interpretation. Plymouth: PRIMER-E.

DOBHAL, P.K., KOHLI, R.K. and BATISH, D.R., 2011. Impact of Lantana camara $\mathrm{L}$. invasion on riparian vegetation of Nayar region in Garhwal Himalayas (Uttar akhand, India). Journal of Ecology and the Natural Environment, vol. 3, pp. 11-22.

DOGRA, K.S., SOOD, S.K., DOBHAL, P.K. and SHARMA, S., 2010. Alien plant invasion and their impact on indigenous species diversity at global scale: a review. Journal of Ecology and the Natural Environment, vol. 2, pp. 175-186.

DUGGIN, J.A. and GENTLE, C.B., 1998. Experimental evidence on the importance of disturbance intensity for invasion of Lantana camara $\mathrm{L}$. in dry rainforest-open forest ecotones in north-eastern NSW, Australia. Forest Ecology and Management, vol. 109, no. 1-3, pp. 279-292. http://dx.doi.org/10.1016/S0378-1127(98)00252-7.

ETANA, B., 2013. Distribution and challenges of an invasive exotic species, Prosopis juliflora (Sw.) DC. (Fabaceae) in Ethiopia, East Africa. International Journal of Green and Herbal Chemistry, vol. 2, pp. 110-120.

FAN, L., CHEN, Y., YUAN, J. and YANG, Z., 2010. The effect of Lantana camara Linn. invasion on soil chemical and microbiological properties and plant biomass accumulation in southern China. Geoderma, vol. 154, no. 3-4, pp. 370-378. http:// dx.doi.org/10.1016/j.geoderma.2009.11.010.

FATIMAH, H. and AHMAD, T., 2012. Invasion of Parthenium hysterophorus in the twin cities Islamabad and Rawalpindi. International Journal of Basic \& Applied Sciences, vol. 1, pp. 303-313.

GHUFRAN, M.A., HAMID, N., ALI, A. and ALI, S.M., 2013. Prevalence of allergenic pollen grains in the city of Islamabad, Pakistan and its impact on human health. Pakistan Journal of Botany, vol. 45, pp. 1387-1390.

GLOBAL INVASIVE SPECIES PROGRAM - GISP [online], 2020 [viewed 2 April 2019]. Available from: http://www.gisp.org/.

GONCALVES, E., HERRERA, I., DUARTE, M., BUSTAMANTE, R.O., LAMPO, M., VELÁSQUEZ, G., SHARMA, G.P. and GARCÍA-RANGEL, S., 2014. Global Invasion of Lantana camara: has the climatic niche been conserved across continents? PLoS One, vol. 9, no. 10, pp. 1-11. http://dx.doi.org/10.1371/ journal.pone. 0111468

GOODEN, B., FRENCH, K. and TURNER, P.J., 2009. Invasion and management of a woody plant, Lantana camara L., alters vegetation diversity within wet sclerophyll forest in southeastern Australia. Forest Ecology and Management, vol. 257, pp. 960-967.

GRICE, A.C., 2006. The impacts of invasive plant species on the biodiversity of Australian rangelands. The Rangeland Journal, vol. 28, no. 1, pp. 27-35. http://dx.doi.org/10.1071/RJ06014.

HEJDA, M., PYSEK, P. and JAROSIK, V., 2009. Impact of invasive plants on the species richness, diversity and composition of invaded communities. Journal of Ecology, vol. 97, no. 3, pp. 393-403. http://dx.doi.org/10.1111/j.1365-2745.2009.01480.x.

JESCHKE, J.M., BACHER, S., BLACKBURN, T.M., DICK, J.T.A., ESSL, F., EVANS, T., GAERTNER, M., HULME, P.E., KUHN, I., MRUGALA, A., PERGL, J., PYSEK, P., RABITSCH, W., RICCIARDI, A., RICHARDSON, D.M., SENDEK, A., VILA, M., WINTER, M. and KUMSCHICK, S., 2014. Defining the impact of non-native species. Conservation Biology, vol. 28, no. 5, pp. 1188-1194. http://dx.doi.org/10.1111/cobi.12299. PMid:24779412

KHAN, M. A., QURESHI, R. A., GILLANI, S. A., GHUFRAN, M. A., BATOOL, A., and SULTANA, K. N., 2010. Invasive species of federal capital area Islamabad, Pakistan. Pakistan Journal of Botany, vol. 42, pp. 1529-1534.

LEMMA, B., TESSEMA, T. and FESSEHAIE, R., 2015. Distribution, abundance and socio-economic impacts of invasive plant species (IPS) in Borana and Guji Zones of Oromia National Regional State, Ethiopia. Basic Research Journal of Agricultural Science and Review, vol. 4, pp. 271-279.

MALIK, R.N. and HUSAIN, S.Z., 2006. Classification and ordination of vegetation communities of the Lohibehr reserve forest and its surrounding areas, Rawalpindi, Pakistan. Pakistan Journal of Botany, vol. 38, pp. 543-558.

MANCHESTER, J.S. and BULLOCK, J.M., 2000. The impacts of non-native species on UK biodiversity and the effectiveness of control. Journal of Applied Ecology, vol. 37, no. 5, pp. 845-864. http://dx.doi.org/10.1046/j.1365-2664.2000.00538.x.

MARWAT, K.B., HASHIM, S. and ALI, H., 2010. Weed management: A case study from North-West Pakistan. Pakistan Journal of Botany, vol. 42, pp. 341-353. 
MCNEELY, J., 2001. Invasive species: a costly catastrophe for native biodiversity. Land Use and Water Resources Research, vol. 2, pp. 1-10.

PANETTA, F.D. and GOODEN, B., 2017. Managing for biodiversity: impact and action thresholds for invasive plants in natural ecosystems. NeoBiota, vol. 34, pp. 53-66. http://dx.doi. org/10.3897/neobiota.34.11821.

PRIYANKA, N. and JOSHI, P.K., 2013. A review of Lantana camara studies in India. International Journal of Scientific and Research Publications, vol. 3, pp. 1-11.

QURESHI, H., ARSHAD, M. and BIBI, Y., 2014. Invasive flora of Pakistan: A critical analysis. International Journal of Biosciences, vol. 4, pp. 407-424.

QURESHI, H., ANWAR, T., ARSHAD, M., OSUNKOYA, O.O. and ADKINS, S.W., 2019. Impacts of Xanthium strumarium L. invasion on vascular plant diversity in Pothwar Region (Pakistan). Annali di Botanica, vol. 9, pp. 73-82. http://dx.doi. org/10.13133/2239-3129/14411.

RASHID, K. and RASUL, G., 2011. Rainfall variability and Maize production over the Potohar Plateau of Pakistan. Pakistan Journal of Meteorology, vol. 8, pp. 63-74.

RIAZ, T. and JAVAID, A., 2010. Prevalence of invasive Parthenium weed in District Hafizabad, Pakistan. The Journal of Animal and Plant Sciences, vol. 20, pp. 90-93.

RIAZ, T. and JAVAID, A., 2011. Prevalence of alien weed Parthenium hysterophorus L. in grazing and wastelands of district Attock, Pakistan. The Journal of Animal and Plant Sciences, vol. 21 , pp. $542-545$.

SHABBIR, A. and BAJWA, R., 2007. Parthenium invasion in Pakistan-A threat still unrecognized. Pakistan Journal of Botany, vol. 39, pp. 2519-2526.

SHABBIR, A., DHILEEPAN, K. and ADKINS, S.W., 2012. Spread of Parthenium weed and its biological control agent in the Punjab, Pakistan. Pakistan Journal of Weed Science Research, vol. 18 , pp. 581-588.

SHACKLETON, R.T., WITT, A.B.R., AOOL, W. and PRATT, C.F., 2017. Distribution of the invasive alien weed, Lantana camara, and its ecological and livelihood impacts in eastern Africa. African Journal of Range \& Forage Science, vol. 34, no. 1, pp. 1-11. http://dx.doi.org/10.2989/10220119.2017.1301551.
SHARMA, P., SINGH, P. and TIWARI, A.K., 2009. Effects of Lantana camara invasion on plant biodiversity and soil erosion in a forest watershed in lower Himalayas, India. Indian Journal of Forestry, vol. 32, pp. 369-374.

SHAUKAT, S.S., SIDDIQUI, I.A., ALI, N.I., ALI, S.A. and KHAN, G.H., 2003. Nematicidal and allelopathic responses of Lantana camara root extract. Phytopathologia Mediterranea, vol. 42 , pp. $71-78$.

SINGH, H.P., BATISH, D.R., DOGRA, K.S., KAUR, S., KOHLI, R.K. and NEGI, A., 2014. Negative effect of invasive weed Lantana camara on structure and composition of vegetation in the lower Shhiwalik Hills, Nothern India. Environmental Monitoring and Assessment, vol. 186, no. 6, pp. 3379-3389. http://dx.doi. org/10.1007/s10661-014-3624-x. PMid:24477614.

TADESSE, N.S., ASSEFA, A.S., MOTBAYNOR, M.M., BETSIHA, E.M., HAILU, A.A., BEYENE, G.F. and HORDOFA, T.B., 2017. Invasion and impacts of Xanthium strumarium in Borena Zone of Oromia Region, Ethiopia. Journal of Coastal Life Medicine, vol. 5, pp. 350-355. http://dx.doi.org/10.12980/jclm.5.2017J7-26.

TAYLOR, S. and KUMAR, L., 2014. Climate change and weed impacts on small island ecosystems: Lantana camara L. (Magnoliopsida: Verbenaceae) distribution in Fiji. Pacific Science, vol. 68, no. 1, pp. 117-133. http://dx.doi.org/10.2984/68.1.11.

TAYLOR, S., KUMAR, L., REID, N. and KRITICOS, D.J., 2012. Climate change and the potential distribution of an invasive shrub, Lantana camara L. PLoS One, vol. 7, no. 4, pp. e35565. http://dx.doi.org/10.1371/journal.pone.0035565. PMid:22536408.

VARDIEN, W., RICHARDSON, D.M., FOXCROFT, L.C., THOMPSON, G.D., WILSON, J.R.U. and LE ROUX, J.J., 2012. Invasion dynamics of Lantana camara L. (sensu lato) in South Africa. South African Journal of Botany, vol. 81, pp. 81-94. http:// dx.doi.org/10.1016/j.sajb.2012.06.002.

YADAV, V., SINGH, N.B., SINGH, H., SINGH, A. and HUSSAIN, I., 2016. Allelopathic invasion of alien plant species in India and their management strategies: a review. Tropical Plant Research, vol. 3, pp. 87-101.

ZHANG, Q., ZHANG, Y., PENG, S. and ZOBEL, K., 2014. Climate warming may facilitate invasion of the exotic shrub Lantana camara. PLoS One, vol. 9, no. 9, pp. e105500. http:// dx.doi.org/10.1371/journal.pone.0105500. PMid:25184224. 